\title{
Carney Complex, a Familial Multiple Neoplasia and Lentiginosis Syndrome Analysis of 11 Kindreds and Linkage to the Short Arm of Chromosome 2
}

\author{
Constantine A. Stratakis, ${ }^{\star}$ J. Aidan Carney, ${ }^{\ddagger}$ Jing-Ping Lin, ${ }^{\S}$ Dimitris A. Papanicolaou, ${ }^{\star}$ Michael Karl, ${ }^{\star}$ Daniel L. Kastner," \\ Elon Pras," and George P. Chrousos* \\ *Section on Pediatric Endocrinology, Developmental Endocrinology Branch, National Institute of Child Health \& Human Development, \\ National Institutes of Health (NIH), Bethesda, Maryland 20892, ${ }^{\circ}$ Department of Laboratory Medicine and Pathology, Mayo Clinic,

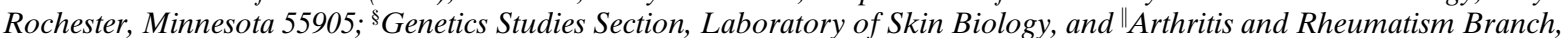 \\ National Institute of Arthritis, Musculoskeletal and Skin Diseases, NIH, Bethesda, Maryland 20892
}

\begin{abstract}
Carney complex is an autosomal dominant syndrome characterized by multiple neoplasias, including myxomas at various sites and endocrine tumors, and lentiginosis. The genetic defect(s) responsible for the complex remain(s) unknown. We studied 101 subjects, including 51 affected members, from 11 North American kindreds with Carney complex. Blood samples were collected from patients and their family members. Hospital records, photographs, and tissue specimens of deceased individuals were reviewed. DNA was extracted from blood samples, patient-derived cell lines, and/ or paraffin-embedded tissues. Linkage analysis was performed with highly polymorphic microsatellite markers, distributed over areas of the human genome harboring the most likely candidate genes. The most prevalent clinical manifestation in patients with Carney complex was spotty skin pigmentation, similar to that observed in Peutz-Jeghers and other lentiginosis syndromes. Skin and cardiac myxomas, Cushing syndrome, and acromegaly were present in $62,30,31$, and 8 percent of the patients, respectively. Linkage was obtained for three markers on the short arm of chromosome 2 (2p16), with a maximum two-point lod score of 5.97 at $\boldsymbol{\theta}=\mathbf{0 . 0 3}$ for the marker CA-2 (odds in favor of linkage $\left.10^{6}: 1\right)$. The flanking markers CA7 and D2S378 defined a region of $\sim 6.4 \mathrm{cM}$ that is likely to contain the gene(s) associated with Carney complex. Candidate genes in the proximity, including the propiomelanocortin and the DNA-mismatch repair $h M S H 2$ genes, were excluded. We conclude that the genetic $\operatorname{defect}(\mathrm{s})$ responsible for Carney complex map(s) to the short arm of chromosome 2 (2p16). This region has exhibited cytogenetic aberrations in atrial myxomas associated with the complex, and has been characterized by microsatellite instability in human neoplasias. (J. Clin. Invest. 1996. 97:699-705.) Key words: Carney complex - multiple endocrine neoplasia (MEN) - myxomas • linkage $\bullet$ chromosome $2 p$
\end{abstract}

\footnotetext{
Address correspondence to Constantine A. Stratakis, National Institute of Child Health \& Human Development, National Institutes of Health, Building 10, Room 10 N 262, 9000 Rockville Pike, Bethesda, MD 20892-1862. Phone: 301-496-4686; FAX: 301-402-0574; E-mail: stratakc@cc1.nichd.nih.gov

Received for publication 13 July 1995 and accepted in revised form 5 October 1995.
}

The Journal of Clinical Investigation

Volume 97, Number 3, February 1996, 699-705

\section{Introduction}

Carney complex is a familial multiple neoplasia and lentiginosis syndrome. Historically, the complex described the association of: (a) primary pigmented nodular adrenocortical disease (PPNAD), a pituitary-independent, primary adrenal form of hypercortisolism, $(b)$ lentigines, ephelides and blue nevi of the skin and mucosae, and (c) a variety of nonendocrine and endocrine tumors (1). The latter include myxomas of the skin (2), heart (3-5), breast (6), and other sites (7-10), psammomatous melanotic schwannoma $(11,12)$, growth hormone-producing pituitary adenoma (13), testicular Sertoli cell tumor (14), and possibly other benign and malignant neoplasms, including tumors of the thyroid gland and ductal adenoma of the breast (1, 15). Although the existence of the complex as an unrecognized, inherited syndrome was first suggested in $1985(16,17)$, combinations of several components of the syndrome, and their familial occurrence had been reported earlier. Thus, the pathologic findings of the adrenal glands, multiple, small, pigmented, adrenocortical nodules and internodular cortical atrophy, were described in children and young adults with Cushing syndrome as early as in 1949 (18-22). Similarly, by then, several familial cases of cutaneous and cardiac myxomas associated with lentigines (lentigo simplex) or ephelides and blue nevi of the skin and mucosae had been described under the acronyms, NAME (for nevi, atrial myxoma, myxoid neurofibromata, and ephelides) and LAMB (for lentigines, atrial myxoma, mucocutaneous myxoma, blue nevi) syndromes $(16,17$, 23-30).

Carney complex has some similarities with, but also major differences from the familial multiple endocrine neoplasia (MEN) syndromes MEN-I, MEN-II A, and -II B and the lentiginoses. It shares Cushing syndrome with the MENs, but this is uniquely caused by PPNAD in the complex. It also shares with them acromegaly due to a growth hormone-producing pituitary adenoma. This tumor, common in MEN-I, is relatively infrequent in the complex $(13,31)$. Likewise, Carney complex shares characteristic spotty skin pigmentation with the familial lentiginoses, which include the Peutz-Jeghers syndrome, the syndrome of lentigines and hypertrophic cardiomyopathy known by the acronym "LEOPARD," and the newly described "syndrome of arterial dissections with lentiginosis" (32-34). Interestingly, large-cell calcifying Sertoli cell tumors, which occur in Carney complex, are also occasionally seen in Peutz-Jeghers syndrome, as also are breast, ovarian and thy-

1. Abbreviations used in this paper: MEN, multiple endocrine neoplasia; PPNAD, primary pigmented nodular adrenocortical disease; POMC, propiomelanocortin. 
roid neoplasias (35). Finally, Carney complex, like the MEN, Peutz-Jeghers and LEOPARD syndromes, is inherited in an autosomal dominant manner (36).

The chromosomal loci of and/or the genetic defects leading to MEN-I and MEN-IIA and -IIB have been mapped to chromosome 11 and 10, respectively, while they remain unknown in Carney complex and the lentiginosis syndromes (37-39). In the present study, we analyzed the clinical data of 11 kindreds with Carney complex from the United States and Canada and collected blood for DNA extraction from their members. We performed linkage analysis using highly polymorphic markers from areas of the human genome likely to be involved. These were the chromosomal loci associated with cytogenetic aberrations of atrial myxomas excised from patients with the complex (40-42), those of the propiomelanocortin (POMC) gene, corticotropin- and melanotropin-receptor genes, as well as of several components of the guanine-nucleotide binding protein (G-protein) pathway, which mediates corticotropic and melanotropic actions (43-46).

\section{Methods}

Patients. The institutional review boards of National Institute of Child Health and Human Development, NIH, and the Mayo Clinic approved the contact of families with Carney complex and the participation of patients and their relatives in this study, after giving informed consent. The families were seen by two of the authors (C.A.
Stratakis and J.A. Carney). Hospital records, biopsy reports, and other clinical information were reviewed. Tissue slides of lesions excised from affected patients were reviewed by one of the authors (J.A. Carney) for confirmation of the diagnosis. Clinical photographs were obtained from all participating individuals and deceased individuals. For the latter, hospital records, pathologic slides, and formalin-fixed, paraffin-embedded tissues were obtained whenever possible, after a request signed by a first-degree relative was placed to the responsible institution. Blood and tissue samples were collected from a total of 101 persons from 11 families located throughout the United States (10 families) and Canada (1 family) (Fig. 1). Kindreds evaluated by NIH were assigned a two-digit code number (CAR01 through 03), whereas those evaluated by Mayo Clinic, a three-digit code number (CAR101 through 108). Each sample was given a two-digit number that reflected the order of its collection (for example, CAR107.03 represents the third specimen collected from the CAR.107 family). Clinical information for most of these families has been reported before $(5,10,16,47-54)$.

Analysis of clinical data. Patients who had at least two of the characteristic lesions of the complex were included in the analysis as affected with Carney complex. The lesions were: cardiac, eyelid, ear, oral, nasal, vulvar, penile, and other site skin myxoma, breast, and/or uterine myxoid tumor, psammomatous melanotic schwannoma, PPNAD, growth hormone-producing pituitary adenoma, testicular Sertoli cell tumor, and spotty skin and mucosal pigmentation. Persons who were older than 20 years of age and lacking two of the above findings were considered unaffected. Seven subjects were included as unknown (noted with a question mark [?] in the kindred pedigrees [Fig. 1]), because conclusive information could not be obtained about
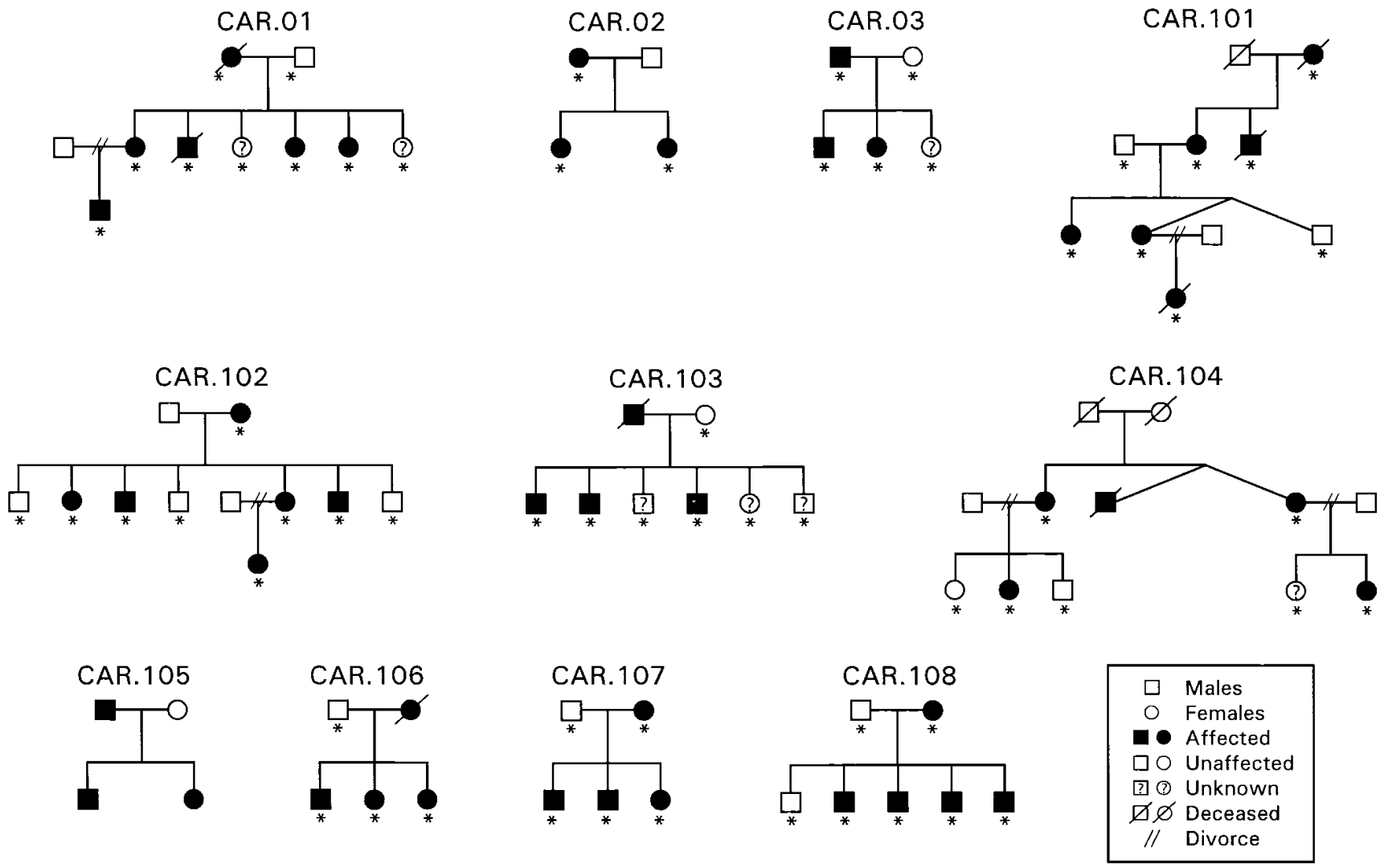

Figure 1. Pedigrees of the 11 families included in the study (clinical information in 9 of the 11 kindreds was reported previously: CAR01 [47], CAR02 [48], CAR101 [5, 49], CAR102 [36, 50], CAR103 [51], CAR104 [52], CAR105 [53, 54], CAR107 [10], and CAR108 [16]). Open squares and circles represent unaffected male and female patients, respectively. Solid squares and circles represent affected subjects. Symbols crossed by a line represent deceased individuals. The individuals marked with a question mark were of unknown affectation status. Individuals used in the linkage study are indicated by an asterisk. Two lines crossing an horizontal line between a husband and a wife indicate separation or divorce; a blood sample was not obtained in most of these cases. 
their status. 51 affected patients were used in the clinical analysis (Table I). Eight of these were not used in the linkage analysis because a specimen was not available. 64 samples were typed (indicated with an asterisk [*] in Fig. 1) for the linkage study, including 43 affected, 14 unaffected, and 7 unknown status individuals.

Establishment of permanent cell lines and DNA preparation. $20 \mathrm{ml}$ of blood was obtained from each person in an heparinized syringe and tube. The PBL were separated on a Ficoll gradient and immortalized with EBV, as previously described (55). For DNA extraction, $10^{6}$ cells were added to a $10 \%$ Chelex 100 resin solution (Bio-Rad Laboratories, Hercules, CA), heated at $95^{\circ} \mathrm{C}$ for $10 \mathrm{~min}$, then placed on ice for $1 \mathrm{~min}$, centrifuged at $12,000 \mathrm{rpm}$ for $3 \mathrm{~min}$, and the supernatant was collected for use. A commercial kit was used for extraction of DNA from paraffin-embedded tissue specimens (Oncor Inc., Gaithersburg, MD).

PCR conditions and primers. PCR analysis was performed with polymorphic markers (Research Genetics, Huntsville, AL) from the GENETHON published map of the human genome (56). The markers CA2, CA5, CA7, CA16, CA18 on chromosome $2 p$ and the trinucleotide-repeat polymorphism from within the POMC gene had been previously reported (57-59). For each of the markers, the reverse primer was end-labeled with $\gamma-{ }^{32} \mathrm{P}$, using polynucleotide kinase (New England Biolabs, Beverly, MA) (60). $10 \mu \mathrm{g}$ of DNA was used in each PCR. The reaction was carried out in a $10 \mu \mathrm{l}$ volume containing $1 \mu \mathrm{l}$ of DNA solution, $10 \mathrm{pmol}$ of each unlabeled primer, $20 \mu \mathrm{g}$ of each dNTP, 0.1 pmol of ${ }^{32} \mathrm{P}$-labeled primer, in $1.5 \mathrm{mM} \mathrm{MgCl}_{2}$ PCR buffer, and $1 \mathrm{U}$ of $\mathrm{Taq}$ polymerase (Perkin-Elmer Roche, Branchburg, NJ). $10 \%$ DMSO (Sigma Chemical Co., St. Louis, MO) was added in the reaction mixture for the CA2-CA18 markers. 30 cycles were performed $\left(94^{\circ} \mathrm{C}\right.$ for $1 \mathrm{~min}, 57^{\circ} \mathrm{C}$ for $1 \mathrm{~min}, 72^{\circ} \mathrm{C}$ for $\left.30 \mathrm{~s}\right)$, followed by a final $10 \mathrm{~min}$ extension at $72^{\circ} \mathrm{C}$. The conditions for the CA2-CA18 markers were slightly different $(57,58)$. For the POMC gene marker, $\alpha{ }^{3}{ }^{33} \mathrm{P}$ was used in the PCR mixture instead of an end-labeled primer. The conditions of the reaction were as previously described (59). Aliquots of amplified DNA were mixed with an equal volume of loading buffer, denatured at $94^{\circ} \mathrm{C}$ for $5 \mathrm{~min}$, and electrophoresed on a $6 \%$ polyacrylamide gel (Promega Corp., Madison, WI).

Linkage analysis. We confirmed autosomal dominant inheritance of Carney complex in our patient population by performing segregation analysis of families with a proband parent, thus avoiding an ascertainment bias. Kindreds with an offspring of unknown clinical status were not included in this analysis (data not shown). Linkage

Table I. Clinical Manifestations of Carney Complex among 51 Patients in 11 Families

\begin{tabular}{|c|c|c|}
\hline & Number of Patients & Percent affected \\
\hline \multicolumn{3}{|l|}{ Tumors } \\
\hline \multicolumn{3}{|l|}{ Myxomas: } \\
\hline Cardiac & 15 & 30 \\
\hline Palpebral & 13 & 26 \\
\hline Aural & 7 & 14 \\
\hline Oral & 1 & $<2$ \\
\hline Nasal & 2 & 4 \\
\hline Penile & 1 & $<2$ \\
\hline Skin (other sites) & 32 & 63 \\
\hline \multicolumn{3}{|l|}{ Myxoma or myxoid tumor: } \\
\hline Breast & 11 ( 1 in a male patient) & 22 \\
\hline Uterine & 1 & $<2$ \\
\hline Psammomatous melanotic schwannoma & 9 & 18 \\
\hline PPNAD & 16 & 32 \\
\hline \multicolumn{3}{|l|}{ Acromegaly (growth hormone-producing } \\
\hline pituitary adenoma & 4 & 8 \\
\hline Sertoli cell testicular tumor & 7 & 14 \\
\hline Thyroid tumors* & 5 & 10 \\
\hline Other lesions ${ }^{\ddagger}$ & 8 & 16 \\
\hline \multicolumn{3}{|l|}{ Pigmentation } \\
\hline \multicolumn{3}{|l|}{ Spotty pigmentation: } \\
\hline Face, lips & 49 (5 not on the lips) & $96(10 \%$ not on the lips $)$ \\
\hline Trunk & 18 & 35 \\
\hline LEOPARD-like & 2 & 4 \\
\hline Conjunctiva & 18 & 35 \\
\hline Junctional or compound nevi & 33 & 65 \\
\hline Sudden or near-death events & {$[8]^{\S}$} & {$[16]$} \\
\hline \multicolumn{3}{|l|}{ Psammomatous melanotic } \\
\hline schwannoma (Esophageal obstruction) & 1 & $<2$ \\
\hline Strokes & 4 & 8 \\
\hline Childhood sudden death & 1 & $<2$ \\
\hline Cushing syndrome complications & 2 & 4 \\
\hline
\end{tabular}

*Thyroid tumors included (in parentheses the number of patients): thyroid papillary carcinoma (1), benign thyroid nodules and cysts (4). ${ }^{\ddagger} \mathrm{Other}$ tumors included (in parentheses the number of patients): colorectal cancer (1), pancreatic adenocarcinoma (1), lung granuloma (1), atypical adrenocortical neoplasm (1), testicular adrenal rest tumor (1), angiomyxoma (1), spermatocele (1), ovarian cystadenoma (1). ${ }^{\S}$ The total number of sudden deaths or near-death events and their incidence is given in brackets. 
analysis was then performed with the LINKAGE (Version 5.1) package of computer programs, assuming a dominant model of inheritance, $100 \%$ penetrance in both sexes, and a gene frequency of 0.0001 (61). Map distances were taken from published sources (56-58). The allele frequencies of all markers were calculated based on 30 chromosomes from the spouses of the patients. Two-point lod scores and multipoint analysis were obtained with the MLINK, LINKMAP, and FASTLINK computer programs, as described before $(55,60,61-63)$.

\section{Results}

Clinical profile. The patients' clinical profile is summarized in Table I. Spotty skin pigmentation, similar to that seen in Peutz-Jeghers and LEOPARD syndromes, was the most common clinical manifestation of Carney complex, present in $96 \%$ of the patients. There was great variability in the number and color of the pigmented spots and the presence of blue nevi. The endocrine manifestations of the complex, namely, acromegaly and Cushing syndrome, were also quite variable. Of major clinical significance was the occurrence of early sudden death or near death events in $16 \%$ of our patients.

Linkage analysis. There was no evidence for linkage on chromosome 18, the long arms of chromosome 16 and 20 and the short arm of chromosome 12, all sites of potential candidate loci $(40-46,64,65)$. Since telomeric translocations of chromosome 2 had been observed in cardiac myxomas and the gene that codes for POMC is located on the short arm of chromosome 2 (2p) $(41,42,46)$, we examined this chromosome for linkage. A maximal two-point lod score over 3 was obtained for three markers on the short arm of chromosome 2 . The markers CA-5, CA-2, and D2S123 produced lod scores of 3.26 $(\theta=0.07), 5.97(\theta=0.03)$, and $3.73(\theta=0.04)$, respectively. Six other markers from this region produced positive lod scores under 3 (Table II). The D2S123 locus has been linked to hereditary nonpolyposis colorectal cancer and a detailed map of this area of the short arm of chromosome $2 \mathrm{p}$ is available (Fig. 2) (57, 66).

Analysis of recombinant haplotypes and multipoint lod score. To determine the most likely position of the Carney complex gene(s) relative to chromosome $2 \mathrm{p}$ loci, we analyzed recombinant haplotypes in the families (Table III). 13 patients had undergone recombination between the CA-16/CA-18 and D2S119 loci. 11 of these individuals appeared to have simple, single recombination events. The most informative of these were in patients CAR01.07, 01.10, 104.08, and 104.10. These

Table II. Pairwise Lod Scores for Chromosome 2p Markers and Carney Complex

\begin{tabular}{|c|c|c|c|c|c|c|c|}
\hline \multirow[b]{2}{*}{ Locus } & \multicolumn{5}{|c|}{ Lod scores at recombination fractions $(\Theta)$} & \multirow[b]{2}{*}{ Zmax } & \multirow[b]{2}{*}{$\Theta \max$} \\
\hline & 0.00 & 0.1 & 0.2 & 0.3 & 0.4 & & \\
\hline D2S119 & - inf. & -0.75 & 0.42 & 0.47 & 0.16 & 0.52 & 0.25 \\
\hline$D 2 S 391$ & - inf. & -0.37 & 0.14 & 0.15 & 0.02 & 0.18 & 0.25 \\
\hline CA-5 & - inf. & 3.18 & 2.46 & 1.46 & 0.5 & 3.26 & 0.07 \\
\hline CA-7 & - inf. & 1.16 & 1.49 & 1.04 & 0.38 & 1.51 & 0.02 \\
\hline$D 2 S 123$ & - inf. & 3.46 & 2.6 & 1.59 & 0.62 & 3.73 & 0.04 \\
\hline CA-2 & - inf. & 5.37 & 3.98 & 2.4 & 0.89 & 5.97 & 0.03 \\
\hline D2S378 & - inf. & 1.20 & 1.58 & 1.13 & 0.40 & 1.60 & 0.18 \\
\hline CA-16 & -inf. & 0.10 & 0.89 & 0.73 & 0.26 & 0.90 & 0.22 \\
\hline CA-18 & -inf. & -0.01 & 0.59 & 0.48 & 0.17 & 0.60 & 0.22 \\
\hline
\end{tabular}

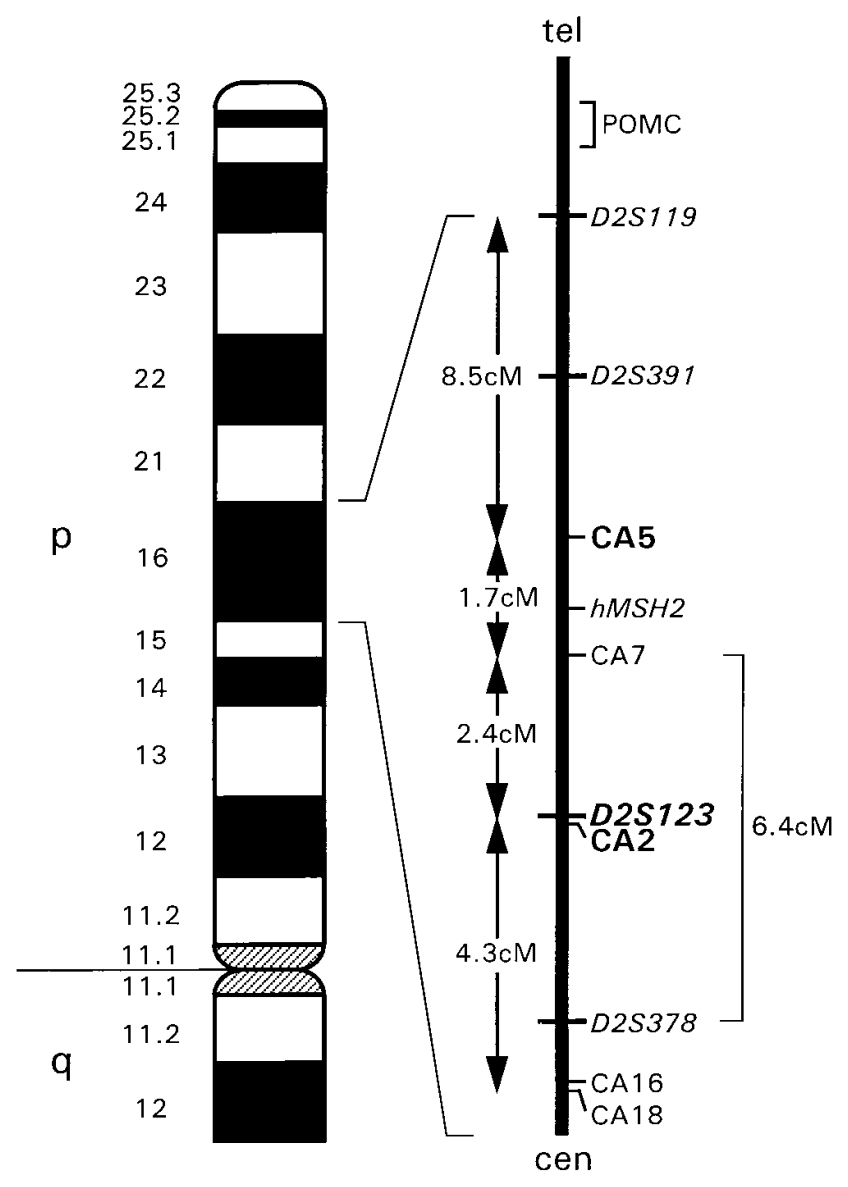

Figure 2. A diagram of the short arm of chromosome 2 (2p), a genetic map of the genome contained between the D2S119 and CA16/ CA18 loci, and the 6.4-cM long area corresponding to the cytogenetic band $2 \mathrm{p} 16$, where the locus for Carney complex is likely to be located. The map order and intermarker distances were published previously $(56,57,67)$.

individuals retained the disease-linked allele for the $D 2 S 123$ and CA-2 markers but had undergone recombination for more distant loci, bordered by the D2S378 markers towards the centromere and the CA-7 marker towards the telomere. Similarly, patient CAR106.07 retained the disease-linked allele for the CA-2 and D2S123 markers. Assuming that the same genetic defect was involved in all the families studied here, the conclusion to be drawn is that the gene responsible for Carney complex is located in an area $\sim 6.4 \mathrm{cM}$ long, bordered by the CA7 and D2S378 markers (Fig. 2).

Multipoint linkage analysis was consistent with this interpretation. Using the CA-2/D2S123, D2S378, and CA-7 loci as fixed points, a maximal multipoint lod score of 3 indicated that the most likely location of the Carney complex gene(s) was $\sim 4 \mathrm{cM}$ centromeric to the CA-2/D2S123 locus (data not shown). One affected individual (CAR102.13) appeared to be a double recombinant for the disease-linked allele (Table III). Because of this individual and the lack of other polymorphic markers within the $6.4 \mathrm{cM}$ region defined by the recombination events shown in Table III, a more refined mapping of the gene(s) for Carney complex was not possible. Family CAR102 demonstrated neither evidence for clinical heterogeneity nor recombination events in members other than CAR102.13 that could have pointed to genetic heterogeneity. 
Table III. Recombination Events between Markers on Chromosome 2p16 and the Disease-linked Allele in patients from 10 Families with Carney Complex



Markers on the short arm of chromosome 2 plotted against each of 13 recombinant members of the Carney complex kindreds. Solid squares represent recombinants, gray squares uninformativeness of the respective marker, and open squares, segregation with the expected allele.

Exclusion of the POMC and hMSH2 genes. The POMC gene, coding for ACTH and $\alpha$-melanocyte-stimulating hormone and previously considered a likely candidate for Carney complex, was mapped by in situ hybridization to chromosome $2 \mathrm{p} 21-22$, an area proximal to $2 \mathrm{p} 16(46,67)$. We used a polymorphic marker from within the coding sequence of the POMC gene (Fig. 2) (59) and excluded the latter as a candidate gene for this disorder. Another gene located in the area, the $h M S H 2$ gene, responsible for DNA stability and tumor suppression, lies in the $8.5-\mathrm{cM}$ region that is bordered by the D2S119 and CA-5 loci on chromosome 2p (Fig. 2) (57, 66, 68). Four affected (CAR01.05 and 01.02, 102.13, and 106.07) and two unaffected (CAR104.08 and 104.10) individuals demonstrated recombination events in this region, making $h M S H 2$ an unlikely candidate gene for Carney complex (Table III).

\section{Discussion}

Carney complex is a rare disorder of unknown incidence and pathogenesis. Close to 200 patients have been reported from diverse ethnic groups, since the initial description of the complex $(1,16,17,64,69-72)$. In the late 1980's, investigators reported the presence of "adrenal-stimulating immunoglobulins" leading to corticotropin-independent adrenocortical nodular hyperplasia in affected subjects and suggested that "Carney complex was an inherited disease of immunological origin" $(52,73)$. In the present study of 11 families with Carney complex from the United States and Canada, we found no evidence of autoimmune disease or immune dysfunction. In addition, sera from patients seen at the National Institutes of Health contained no adrenal-stimulating immunoglobulins by in vitro testing (Gomez, M.T., and G.P. Chrousos, unpublished information).

Like the multiple neoplasia and lentiginosis syndromes, Carney complex affects many organs and systems. The lesions associated with the complex are genetically transmissible and multicentric, often bilateral in paired organs, and originate from cells of mesenchymal (myxomas) or neural crest origin (spotty skin pigmentation, endocrine tumors). These features suggest that the genetic defect(s) leading to Carney complex, is(are) involved in the early development, growth, and proliferation of affected cells. Thus, candidate genes include those involved in tumor suppression and the control of the cell cycle, as well as those with specific effects on the function and growth of mesenchymal and zona fasciculata cells and melanocytes.

To localize the gene(s) for Carney complex, we elected to use the systematic positional cloning approach, starting with linkage analysis, using polymorphic markers from likely areas of the genome. We obtained positive lod scores for nine markers on the short arm of chromosome 2. Three of these markers (CA-5, D2S123, CA-2) gave a maximal two-point lod score of over 3, which is required as evidence for linkage. The CA-2 marker produced a two-point lod score of 5.97, which represents $10^{6}: 1$ odds in favor of linkage of the Carney complex gene(s) with this area of chromosome 2 (2p16). CA-2 lies within $0.001 \mathrm{cM}$ of the $D 2 S 123$ locus. Analysis of the recombination events in the members of the families studied, indicated that two loci (CA-7 and D2S378) bordered a 6.4-cM region that was likely to contain the Carney complex gene(s) (Fig. 2). One affected patient (CAR102.13, Table III), appeared to be a recombinant for the mapped region. Most likely, he had sustained a double recombination that occurred during maternal meiosis. The lack of availability of other polymorphic markers from this area that could define the disease-associated segment of chromosome 2 in this patient, precluded a more refined mapping of the Carney complex locus. Multipoint linkage analysis defined a region $\sim 4$-cM long bordered by the CA-2 and D2S378 markers as the most likely area harboring the responsible gene(s).

The POMC gene is located in the proximity of 2p16 (Fig. 2) and was considered a strong candidate gene for Carney complex because of the role of its proteolytic products in adrenocortical cell and melanocyte growth, proliferation, and function (46). POMC was excluded as a candidate gene for the complex by the recombination events observed in our patients (Table III) and using a trinucleotide-repeat polymorphism from within the POMC-coding sequence. The latter did not segregate with the disease-associated allele in one of our kindreds with no other recombinants for the entire $16.9 \mathrm{cM}$ region that harbored the area between the D2S119 and CA16/CA18 loci.

Hereditary nonpolyposis colorectal cancer, another hereditary neoplasia disorder, was recently mapped to the CA-2/ D2S123 locus (Fig. 2) (66). The gene for hereditary nonpolyposis colorectal cancer was cloned and its coded protein was found to play a direct role in DNA mismatch repair, increasing microsatellite stability and enhancing mutation avoidance in human cells (68). In four patients the disease-associated allele did not segregate with the markers in close proximity to the $h M S H 2$ locus (Table III), making this gene an unlikely candidate for the complex. The recently identified $h M S H 6$ gene, another gene involved in DNA stability, is adjacent to $h M S H 2$, but outside the defined region on 2 p16, that most likely harbors the Carney complex locus (74). Interestingly, this region of chromosome 2 is characterized by microsatellite instability in several human tumors, including nonmelanomatous skin cancer and melanoma $(75,76)$. Its involvement also in the cy- 
togenetic aberrations of cells from cardiac myxomas removed from patients with Carney complex $(41,42)$, suggests the presence in this region of gene(s) with tumor suppression functions that may affect mesenchymal cells, melanocytes, and adrenocortical and other cells.

\section{Acknowledgments}

We received support and encouragement from many scientists from NICHD, NIAMS, and NCGHR and the Mayo Clinic. Our particular thanks to Drs. S. Bale, V. Kimonis, and I. Aksentijevich from the NIH for their help with the linkage analysis, and Dr. R. Jenkins and Mr. P. Stalboerger from the Mayo Clinic for making their laboratory facilities available and for transforming cell lines for us. We thank Drs. N. Nicolaides and N. Papadopoulos (The Johns Hopkins Oncology Center, Baltimore, MD) for kindly providing the sequences of the non-GENETHON markers used in this study. We are indebted to the patients, without whose interest, participation, support, and sacrifice this study could not have been completed. This work is dedicated to them.

\section{References}

1. Carney, J.A., and W.F. Young. 1992. Primary pigmented nodular adrenocortical disease and its associated conditions. The Endocrinologist. 2:6-21.

2. Carney, J.A., J.T. Headington, and W.P.D. Su. 1986. Cutaneous myxomas. A major component of the complex of myxomas, spotty pigmentation, and endocrine overactivity. Arch. Dermatol. 122:790-798.

3. McCarthy, P.M., J.M. Piehler, H.V. Schaff, J.R. Pluth, T.A. Orzulak, H.J. Vidaillet, Jr., and J.A. Carney. 1986. The significance of multiple, recurrent, and "complex" cardiac myxomas. J. Thorac. Cardiovasc. Surg. 91:389-396.

4. Carney, J.A. 1985. Differences between nonfamilial and familial cardiac myxoma. Am. J. Surg. Pathol. 9:53-55.

5. Van Gelder, H.M., D.J. O’Brien, E.D. Staples, and J.A. Alexander. 1992. Familial cardiac myxoma. Ann. Thorac. Surg. 53:419-424.

6. Carney, J.A., and B.C. Toorkey. 1991. Myxoid fibroadenoma and allied conditions (myxomatosis) of the breast: a heritable disorder with special associations including cardiac and cutaneous myxomas. Am. J. Surg. Pathol. 15:713721.

7. Cook, C.A., B.A. Lund, and J.A. Carney. 1987. Mucocutaneous pigmented spots and oral myxomas: the oral manifestations of the complex of myxomas, spotty pigmentation, and endocrine overactivity. Oral Surg. Oral Med. Oral Pathol. 63:175-183.

8. Ferreiro, J.A., and J.A. Carney. 1994. Myxomas of the external ear and their significance. Am. J. Surg. Pathol. 18:274-280.

9. Burgdorf, W.H.C., and G. Koester. 1992. Multiple cutaneous tumors: what do they mean? J. Cutaneous Pathol. 19:449-457.

10. Grossniklaus, H.E., I.W. McLean, and J.J. Gillespie. 1991. Bilateral eyelid myxomas in Carney's complex. Br. J. Ophthalmol. 75:251-252.

11. Utiger, C.A., and J.T. Headington. 1993. Psammomatous melanotic Schwannoma: a new cutaneous marker for Carney's complex. Arch. Dermatol. 129:202-204

12. Carney, J.A. 1990. Psammomatous melanotic schwannoma. A distinctive, heritable tumor with special associations, including cardiac myxoma and the Cushing syndrome. Am. J. Surg. Pathol. 14:206-222.

13. Yen, R.S., B.R. Allen, R. Ott, and M. Brodsky. 1992. The syndrome of right atrial myxoma, spotty skin pigmentation, and acromegaly. Am. Heart J. 123:243-244

14. Manthos, C.L., R.S. Sutherland, J.E. Sims, and J.J. Perloff. 1993. Carney's complex with hormone-producing Sertoli cell tumor of the testicle. $J$. Urol. 150:1511-1512.

15. Carney, J.A., and B.C. Toorkey. 1991. Ductal adenoma of the breast with tubular futures. A probable component of the complex of myxomas, spotty pigmentation, endocrine overactivity, and schwannomas. Am. J. Surg. Pathol. 15:722-731.

16. Carney, J.A., H. Gordon, P.C. Carpenter, B.V. Shenoy, and V.L.W. Go. 1985. The complex of myxomas, spotty pigmentation, and endocrine overactivity. Medicine (Baltimore). 64:270-283.

17. Shenoy, B.V., P.C. Carpenter, and J.A. Carney. 1984. Bilateral primary pigmented nodular adrenocortical disease. Rare cause of the Cushing syndrome. Am. J. Surg. Pathol. 8:335-344.

18. Chute, A.L., G.C. Robinson, and W.L. Donoghue. 1949. Cushing's syndrome in children. J. Pediatr. 34:30-39.

19. De Moor, P., H. Roels, K. Delaere, and J. Crabbe. 1965. Unusual case of adrenocortical hyperfunction. J. Clin. Endocrinol. \& Metab. 25:612-620.

20. Meador, C.K., B. Bowdoin, W.C. Owen, and T.A. Farmer. 1967. Pri- mary adrenocortical nodular dysplasia: a rare cause of Cushing's syndrome. $J$. Clin. Endocrinol. \& Metab. 27:1255-1263.

21. Ruder, H.J., D.L. Loriaux, and M.B. Lipsett. 1974. Severe osteopenia in young adults associated with Cushing's syndrome due to micronodular adrenal disease. J. Clin. Endocrinol. \& Metab. 39:1138-1147.

22. Marova, E.I., M.E. Bronstein, K.N. Kazeev, and N.P. Yuryeva. 1980 Microadenomatosis of the adrenal cortex and hypercortisolism in pubertal age. Sov. Med. 3:15-20.

23. Laboux, L., J. Mussini-Montpellier, J.L. Michaud, F. Gaillard, C. Pelleray, and E. Cornet. 1978. Myxome du ventricule droit chez des jurneaux monozygotes. Ablation chirurgicale. Arch. Mal. Coeur. 8:953-959.

24. Atherton, D.J., D.W. Pitcher, R.S. Wells, and D.M. Macdonald. 1980. A syndrome of various cutaneous pigmented lesions, myxoid neurofibromata and atrial myxoma: the NAME syndrome. Br. J. Dermatol. 103:421-429.

25. Rhodes, A.R., R.A. Silverman, T.J. Harrist, and A.R. Perez-Atayde. 1984. Mucocutaneous lentigines, cardiomucocutaneous myxomas, and multiple blue nevi: the "LAMB" syndrome. J. Am. Acad. Dermatol. 10:72-82.

26. Schweizer-Cagianut, M., E.R. Froesch, and C.E. Hedinger. 1980. Familial Cushing's syndrome with primary adrenocortical microadenomatosis (primary adrenocortical nodular dysplasia). Acta Endocrinol. 94:529-535.

27. Schweizer-Cagianut, M., R. Salomon, and C.E. Hedinger. 1982. Primary adrenocortical nodular dysplasia with Cushing's syndrome and cardiac myxomas: a peculiar familial disease. Virchows Arch. Pathol. Anat. 397:183-192.

28. Houwen, R.H.J., S.L.S. Drop, F.W.J. Hazebroek, and F.W. ten Kate. 1983. Pituitary-dependent Cushing disease and primary adrenocortical nodular dysplasia in childhood. Presentation of 4 cases. Eur. J. Pediatr. 141:101-108.

29. Salomon, F., E.R. Froesh, and C.E. Hedinger. 1990. Familial Cushing's syndrome ("Carney complex") (letter) N. Engl. J. Med. 322:1470.

30. Carney, J.A. 1990. Familial Cushing's syndrome ("Carney complex") (letter) N. Engl. J. Med. 322:1470.

31. Gagel, R.F. 1992. Multiple Endocrine Neoplasia. In Williams Textbook of Endocrinology, J.D. Wilson, and D.W. Foster, editors. W.B. Saunders Co., Philadelphia, 1537-1553.

32. Jeghers, H., V.A. McKusick, and K.H. Katz. 1949. Generalized intestinal polyposis and melanin spots of the oral mucosa, lips and digits: a syndrome of diagnostic significance. N. Engl. J. Med. 241:1031-1036.

33. Senanez, H., F. Maine-Garzon, and R. Kolski. 1976. Cardiocutaneous syndrome (the LEOPARD syndrome). Review of the literature and a new family. Clin. Genet. 9:266-276.

34. Michels, V.V., B. Mokri, D.G. Piergras, and H.O. Perry. 1995. Brief report: a familial syndrome of arterial dissections with lentiginosis. N. Engl. J. Med. 332:576-579.

35. Rustgi, A.K. 1994. Hereditary gastrointestinal polyposis and non-polyposis syndromes. N. Engl. J. Med. 331:1694-1702.

36. Carney, J.A., L.S. Hruska, G.D. Beauchamp, and H. Gordon. 1986 Dominant inheritance of the complex of myxomas, spotty pigmentation, and endocrine overactivity. Mayo Clin. Proc. 61:165-172.

37. Calender, A., I. Schuffenecker, and G.M. Lenoir. 1992. The genetics of multiple endocrine neoplasia (MEN). Horm. Res. 38(Suppl. 2):16-23.

38. Mulligan, L.M., C. Eng, C.S. Healey, D. Clayton, J.B.J. Kwok, E. Gardner, M.A. Ponder, A. Frilling, C.E. Jackson, H. Lehnert, et al. 1994. Specific mutations of the RET proto-oncogene are related to disease phenotype in MEN 2A and FMTC. Nat. Genet. 6:70-74.

39. Eng, C., D.P. Smith, L.M. Mulligan, M.A. Nagai, C.S. Healey, M.A. Ponder, E. Gardner, G.F.W. Scheumann, C.E. Jackson, A. Tunnacliffe, and B.A.J. Ponder. 1994. Point mutation within the tyrosine kinase domain of the RET proto-oncogene in multiple endocrine neoplasia type $2 \mathrm{~B}$ and related sporadic tumors. Hum. Mol. Genet. 3:237-241.

40. Dewald, G.W., R.J. Dahl, J.L. Spurbeck, J.A. Carney, and H. Gordon. 1987. Chromosomally abnormal clones and nonrandom telomeric translocations in cardiac myxomas. Mayo Clin. Proc. 62:558-567.

41. Dijkhuizen, T., E. van der Derg, W.M. Molenaar, J.J. Meuzelaar, and B. de Jong. 1992. Cytogenetics of a case of cardiac myxoma. Cancer Genet. Cytogenet. 63:73-75.

42. Richkind, K.E., D. Wason, and H.J. Vidaillet. 1994. Cardiac myxoma characterized by clonal telomeric association. Genes Chromosomes \& Cancer. 9:68-71.

43. Gantz, I., T. Yamada, T. Tashiro, Y. Konda, Y. Shimoto, H. Miwa, and J.M. Trent. 1994. Mapping of the gene encoding the melanocortin-1 (alpha-melanocyte stimulating hormone) receptor (MC1R) to human chromosome 16q24.3. Genomics. 19:394-395.

44. Chowdhary, B.P., I. Gustavson, J.E.S. Wilkberg, and V. Chhajlani. 1995. Localization of the human melanocortin-5 receptor gene (MC5R) to chromosome band 18 p11.2 by fluorescence in situ hybridization. Cytogenet. Cell Genet. 68:79-81.

45. Spiegel, A.M., A. Shenker, and L.S. Weinstein. 1992. Receptor-effector coupling by G-proteins: implications for normal and abnormal signal transduction. Endocr. Rev. 13:536-565.

46. Takahashi, H., Y. Hakamata, Y. Watanabe, R. Kikuno, T. Miyata, and S. Numa. 1983. Complete nucleotide sequence of the human corticotropin betalipotropin precursor gene. Nucleic Acids Res. 11:6847-6858.

47. Danoff, A., S. Jormark, D. Lorber, and N. Fleischer. 1987. Adrenocortical micronodular dysplasia, cardiac myxomas, lentigines and spindle cell tu- 
mors: report of a kindred. Arch. Intern. Med. 143:443-448.

48. Wagner, P.D., and T. Bohum. 1994. The Carney complex. Hosp. Physician 30:45-49.

49. Burke, A.P., and R. Virmani. 1993. Cardiac myxoma: a clinicopathologic study. Am. J. Clin. Pathol. 100:671-680.

50. Morgan, D.L., J. Palazola, W. Reed, H.H. Bell, L.H. Kindred, and G.D. Beauchamp. 1977. Left heart myxomas. Am. J. Cardiol. 40:611-614.

51. Kennedy, R.H., J.C. Flanagan, R.C. Eagle, Jr., and J.A. Carney. 1991. The Carney complex with ocular signs suggestive of cardiac myxoma. Am. J. Ophthalmol. 111:699-702.

52. Young, W.F., Jr., J.A. Carney, B.U. Musa, N.M. Wulffraat, J.W. Lens, and H.A. Drexhage. 1989. Familial Cushing's syndrome due to primary pigmented nodular adrenocortical disease. reinvestigation 50 years later. $N$. Engl. J. Med. 321:1659-1664.

53. Cheung, P.S.Y., and N.W. Thompson. 1989. Carney's complex: primary pigmented nodular adrenocortical disease and pigmented and myxomatous lesions. Surg. Gynecol. Obstet. 168:413-416.

54. Bain, J. 1986. Carney's complex. Mayo Clin. Proc. 113:370-377.

55. Pras, E., I. Aksentijevich, L. Gruberg, J.E. Balow, L. Prosen, M. Dean, A.D. Steinberg, M. Pras, and D.L. Kastner. 1992. Mapping of a gene causing familial mediterranean fever to the short arm of chromosome 16. N. Engl. J. Med. 326:1509-1513.

56. GENETHON. 1994. The 1993-1994 Genethon human genetic linkage map. Nat. Genet. 7:221-1246.

57. Leach, F.S., N.C. Nicolaides, N. Papadopoulos, B. Liu, J. Jen, R. Parsons, P. Peltomaki, P. Sistonen, L.A. Aaltonen, M. Nystrom-Lathi, et al. 1993. Mutations of a mutS homolog in hereditary nonpolyposis colorectal cancer. Cell. 75:1215-1225.

58. Leach, F.S., N.C. Nicolaides, P. Sistonen, J.-W. Yu, F.-T. Kao, A. de la Chapelle, K.W. Kinzler, and B. Vogelstein. 1994. Three dinucleotide repeat polymorphisms proximal to the D2S123 locus. Hum. Mol. Genet. 3:2082.

59. Morris, J.C., C.E. Bertram, P.J. Lowry, and D. Savva. 1994. Cryptic trinucleotide repeat polymorphism in the POMC gene. Hum. Mol. Genet. 3:2080.

60. Pras, E., N. Arber, I. Aksentijevich, G. Katz, J.M. Schapiro, L. Prosen, L. Gruberg, D. Havel, U. Liberman, J. Weissenbach, et al. 1994. Localization of a gene causing cystinuria to chromosome 2p. Nat. Genet. 6:415-419.

61. Lathrop, G.M., J.M. Lalouel, C. Julier, and J. Ott. 1984. Strategies for multilocus linkage analysis in humans. Proc. Natl. Acad. Sci. USA. 81:34433446.

62. Cottingham , R.W., Jr., R.M. Idury, and A.A. Schaffer. 1993. Faster sequential genetic linkage computations. Am. J. Hum. Genet. 53:252-263.

63. Schaffer, A.A., S.K. Gupta, K. Shriram, and R.W. Cottingham, Jr. 1994. Avoiding recomputation in genetic linkage analysis. Hum. Hered. 44:225-237.

64. Stratakis, C.A., E. Pras, C. Tsigos, M. Karl, D.A. Papanicolaou, D.L. Kastner, J.A. Carney, and G.P. Chrousos. 1995. Genetics of Carney complex: parent of origin effects and putative non-Mendelian features in an autosomal dominant disorder; absence of common defects of the ACTH receptor and RET genes. Ped. Res. 37:99a (Abstr.)

65. Stratakis, C.A., E. Pras, M. Karl, D.A. Papanicolaou, D.L. Kastner, J.A Carney, and G.P. Chrousos. 1995. Carney complex and primary pigmented nodular adrenocortical disease: segregation, simulation and linkage analysis using the candidate gene approach. 77th Annual Meeting of the Endocrine Society, Washington DC (Abstr.).

66. Peltomaki, P., L.A. Aaltonen, P. Sistonen, L. Pylkkanen, J -P. Mecklin, H. Jarvinen, J.S. Green, J.S. Jass, J.L. Weber, F.S. Leach, et al. 1993. Genetic mapping of a locus predisposing to human colorectal cancer. Science (Wash. DC). 260:810-812.

67. Spurr, N.K., S. Cox, and S. Naylor. 1993. Report and abstracts of the second international workshop on human chromosome 2 mapping. Cytogenet. Cell Genet. 64:69-92.

68. Fishel, R., A. Ewel, S. Lee, M.K. Lescoe, and J. Griffith. 1994. Binding of mismatched microsatellite DNA sequences by the human MSH2 protein. Science (Wash. DC). 266:1403-1405.

69. Milner, M.R., L. Semmes, A. Silverman, and B.M. Shmookler. 1990. Familial Cushing's syndrome ("Carney complex"). (letter) N. Engl. J. Med. 322 1469

70. Handley, J., D. Carson, J. Sloan, M. Walsh, C.D. Thornton, D. Hadden, and E.A. Bingham. 1992. Multiple lentigines, myxoid tumour and endocrine overactivity; four cases of Carney's complex. Br. J. Dermatol. 126:367-371.

71. Ichiba, Y., Y. Nishizaki, and M. Tanizaki. 1992. Cushing's syndrome due to primary pigmented nodular adrenocortical disease with cardiac myxomas and mucocutaneous lentigines. Acta Pediatr. 81:91-92.

72. Baillot, R., J.-F. Tanguay, R. Lebeau, M. Klein, S. Allard, A.M. Grothe, L. Dontigny, P. Page, and R. Cossette. 1992. Syndrome cardio-cutane et myxomes cardiaques: presentation d' un cas et experience chirugicale de 17 ans Can. J. Surg. 35:79-83.

73. Berkhout, F.T., R.J.M. Croughs, N.M. Wulffraat, and H.A. Drexhage. 1989. Familial Cushing's syndrome due to nodular adrenocortical dysplasia is an inherited disease of immunological origin. Clin. Endocrinol. 31:185-191.

74. Palombo, F., P. Gallinari, I. Iaccarino, T. Lettieri, M. Hughes, A. D'Arrigo, O. Truong, J.J. Hsuan, and J. Jirichny. 1995. GTBP, a 160-kilodalton protein essential for mismatch-binding activity in human cells. Science (Wash. DC). 268:1912-1914.

75. Aaltonen, L.A., P. Peltomaki, F.S. Leach, P. Sistonen, L. Pylkannen, J.-P. Mecklin, H. Jarvinen, S.M. Powell, J. Jen, S.R. Hamilton, et al. 1993. Clues to the pathogenesis of familial colorectal cancer. Science (Wash. DC). 260:812816.

76. Quinn, A.G., E. Healy, I. Rehman, S. Sikkink, and J.L. Rees. 1995. Microsatellite instability in human non-melanoma and melanoma skin cancer. $J$. Invest. Dermatol. 104:309-312. 